\title{
Western inferno provokes a lot of finger-pointing, but little action
}

Washington. Ecologists and foresters say that 28 huge and ferocious forest fires now raging in the western United States are part of a worsening trend to be blamed on a century of vain attempts to suppress forest fires in the region. Tangible proposals to reverse those mistakes have been drawn up, but deep divisions between environmentalists, foresters and local people make them unlikely to be implemented.

Five million acres of forest are expected to be lost to fire before the summer is out the second largest loss this century - despite a \$1-billion federal effort employing 150 helicopters, 40 air tankers and 20,000 fire-fighters to douse the flames. Many people see the fires as a 'natural' consequence of drought. But ecologists and foresters agree that these intense fires are not 'natural' at all, but rather the result of a century of land mismanagement that has suppressed regular forest burning and transformed millions of acres of forest into what one recent report called "an explosive time bomb waiting to ignite".

As research reveals more about the natural fires and fires set by native Americans which maintained the forests in the past, a consensus has developed between environmentalists and foresters that the forests urgently need thinning. Most even agree that logging and prescribed fire should both play a role. But bad blood between the two groups means that the fight for money to pay for the new strategy has been in vain - even as the

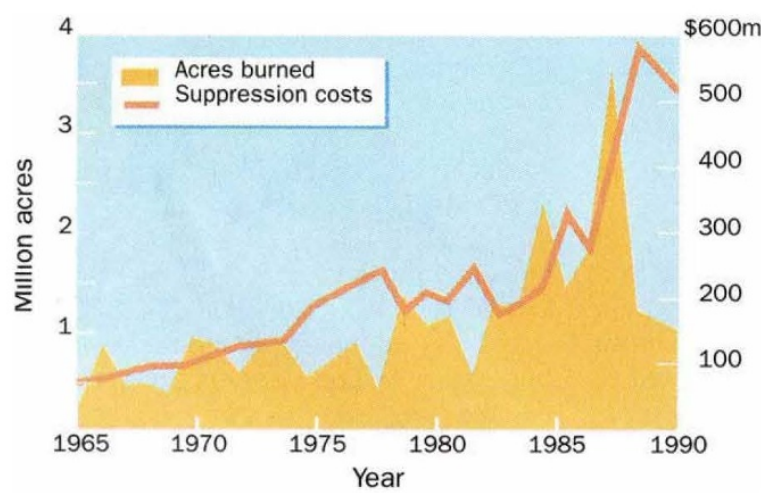

cost of the huge annual fire-fighting operation soars.

Steve Mealey is an old-time forester who supervises the 2.5-million-acre Boise National Forest in Idaho, where 2,000 firefighters are trying to control this year's blazes. He has seen the average annual loss by fire at Boise grow from 3,000 acres a year before 1985 to more than 50,000 acres since.

A cut-away of an aged ponderosa pine tree in Mealey's office explains why. The tree has rings showing that it was scorched rin a forest ecologist at the University of Washington, Seattle. "But when we look to future solutions, the consensus breaks down because it involves a lot more than biology."

Everyone agrees that the forests need thinning. Regular, prescribed burning could keep them thinned, but logging of smaller trees is needed first, to stop the fires burning out of control. The environ-

every sixteen years between 1716 and 1893

not known if Indians or lightning did

burning - but never since.

en European gold-diggers first arcontained about 100

cent fire-resistant ponderosa pine and 30 says Mealey. Today typical acre has more ests throughout th of catastrophic wild-

Defending his Forest Service predecestalists' charges of miswasn't on the table" until the past decade of parent," he explains. Dry weather from 1986 logical wheels started to come off".

Science has the tools to get the wheels back on, but the task is seriously complicated by fighting between the mechanics. "There's a general consensus on why the forests are more susceptible to mental lobby does not trust the foresters to
$\log$ only small trees. And local people ranging from animal lovers to real-estate developers - mistrust prescribed burning. The result is an expensive and dangerous impasse.

Mark Rey, vice-president of the American Forest and Paper Association, says his organization supports both techniques, seeing little difference between them in practice. The real problem is political, he believes. "Environmental activists are unable weather exposed the risk. "We were in a to separate the issue from their antipathy towards logging and forest management," he says. "They'd prefer the issue not be raised, because at its heart is the fact that you can't conserve the forest by walking away from it."
Not surprisingly Jon Roush, the president of the Wilderness Society, rejects this accusation. "I don't know of any mainstream environmental group that would oppose good, strong forest management," he says. The main resistance to change comes from within the federal agencies such as the Forest Service, he contends, adding that "there are people in the forestry industry who see the issue as an opportunity to push for more logging - and to put environmentalists in a bad light".

The warning of a 'time bomb' was issued by a National Commission on Wildfire Disasters, in a strongly worded report delivered earlier this year. The report contains a thorough action plan and a call for further research on the economics of the forest management options it proposes.

The commission was chaired by Neil Sampson, vice-president of the conservation group American Forests. Sampson is trying to build support in Washington for the approach outlined in the report. "Unfortunately, when the flames die down we'll be hard pressed to keep attention on this," he says.

But that may not matter. From the point of view of Congress, the $\$ 1$ billion likely to be spent this year on fire-fighting is "nondiscretionary' spending, and as such counts for little. Funds for a much smaller programme to prevent fire would need to be appropriated from valuable discretionary funds. As one unnamed congressional staff member told Sampson's bemused commission, "we pay agencies to fight fires, not light them".

Colin Macilwain 